\title{
Traditional agro-management practices, utilization and nutritional composition of momala: A local maize variety of Gorontalo, Indonesia
}

\author{
NOVRI YOULA KANDOWANGKO ${ }^{1,2, v}$, MARGARETHA SOLANG ${ }^{2, v v}$, ERNA RETNAWATY ${ }^{3, v v \vee}$ \\ ${ }^{1}$ Department of Biology, Faculty of Mathematics and Natural Sciences, Universitas Negeri Gorontalo. Jl. Jenderal Sudirman No. 6, Gorontalo 96128, \\ Indonesia. Tel./Fax.: +62-435-821125, `email: novrikandowangko@ung.ac.id \\ ${ }^{2}$ Center for Local Wisdom-based Coastal Ecology Research, Department of Biology, Faculty of Mathematics and Natural Sciences, Universitas Negeri \\ Gorontalo. Jl. Jenderal Sudirman No. 6, Gorontalo 96128, Indonesia. Tel./Fax.: +62-435-821125, ^vemail: margarethasolang@ung.ac.id \\ ${ }^{3}$ Gorontalo Assessment Institute for Agricultural Technology. Jl. Kopi No. 270, Iloheluma, Bone Bolango 96583, Gorontalo, Indonesia. \\ Tel.: +62-435) 827627, 8700075, Fax.: +62-435-827627, vemail: ernaretnawati@ pertanian.go.id
}

Manuscript received: 13 November 2019. Revision accepted: 1 January 2020.

\begin{abstract}
Kandowangko NY, Solang M, Retnawaty E. 2020. Traditional agro-management practices, utilization and nutritional composition of Momola-a local maize variety of Gorontalo, Indonesia. Biodiversitas 21: 853-859. Maize (Zea mays, L.) or corn, locally called milu or binthe (Gorontalo language), has been a popular crop among Gorontalo people for a long time. People mostly use baby corn as the main ingredient of binthe biluhuta, famous traditional food in Gorontalo. momala is a local maize variety of Gorontalo the cultivation of which is decreasing. The cause is a shift in farmers' preference of the crop, most of them preferring hybrid variety over momala. Decrease in cultivating local maize has also led to a decline in the local farmers' traditional knowledge of the crop. Therefore, initiatives to raise awareness of the importance of cultivating local crops are essential for their popularization and conservation purposes. This research is aimed at (i) exploring the traditional knowledge of local farmers pertaining to agro-management of maize or corn, (ii) describing the utilization of momala, and (iii) investigating the nutritional composition of momala, both by qualitative and quantitative methods The results revealed that the corn farmers apply the principle of huyula or gotong royong (communal work) in their agriculture activities. The people are using momala corn as the main ingredient of local food preparations, such as binthe biluhuta (clear corn soup), balobinthe (corn rice), and kokole (soft, pudding-like corn cake), in addition to some traditional rituals. Nutritional analysis indicated that its ash content is $1.34-2.86 \%$, crude protein is $9.09-11.67 \%$ crude fat is $4.29-4.96 \%$, and carbohydrate is $67.68-68.16 \%$. Furthermore, the composition of nitrogen-free extract ranges from 57.85-72.96\% and metabolic energy content ranges from 2896.94$3352.77 \mathrm{Kcal} / \mathrm{kg}$. Measures to conserve and improve momala are necessary to promote food security of people.
\end{abstract}

Keywords: Gorontalo, local food, momala maize variety, nutritional composition, traditional agro-management practices

\section{INTRODUCTION}

Corn has played a very important role in industrial development. Almost every part of corn or maize crop can be used as the ingredient of food, animal feed, fuel, and even medicines. For example, corn extract is utilized as an anti-diabetic agent in diabetes mellitus treatment (Karigidi and Olaiya 2019). The orange-yellow maize is well-known as the source of provitamin A carotenoid. Vitamin A precursor has a major role in boosting health and preventing diseases (Hwang et al. 2016).

Maize varies in shape and structure of its kernel; varieties of this crop include sweet corn, Zea mays everta (a variety of maize that its kernels can be processed into popcorn), dent corn, flint corn, pod corn, waxy corn, and QPM or quality protein maize (Subekti et al. 2007). Maize also shows variation in colors, e.g., yellow, white and black. In fact, color is one of the factors used to distinguish between varieties of this crop.

In Indonesia, farmers cultivate maize varieties, such as hybrid maize (Bisi, Pioneer or popular hybrid varieties) and composite or local maize (Arjuna, Manado Yellow, and Bisma). The advantage of planting local maize varieties is their adaptability to local environmental conditions
(Runtunuwu et al. 2014).

One of the local varieties of maize cultivated in Gorontalo, Indonesia is momala, registered in 2018, according to the official report of Plant Variety Protection no. publ.: 27/BR/PVL/01/2018 (PVP 2018), momala is used as a staple food by people in Gorontalo, its utilization is second only to rice. This crop is used as an alternative staple food and also in the preparations such as binthe biluhuta (clear corn soup) or even as an additional ingredient for rice meal, such as balobinthe. momala is widely known for its kernel, which has distinctive redviolet color. Within its silk, anthocyanin pigment is present. Cultivation of this variety is significant in some villages of Gorontalo City and Boalemo Districts, such as Pangeya, Sari Tani, Bongo I, Bongo II, Bongo III Village, Raharja, Tanjung Harapan, Dimito, and Dulohupa Villages (PVP 2018).

Base on observations, some maize farmers are losing interest in growing momala as it is becoming difficult for them to get the seeds. The color of momala kernel which is different from other conventional maize varieties is also worsening the issue. As a result, momala is not preferred by sellers. Most farmers prefer to grow hybrid variety because of easy seed availability, some farmers even get it 
freely. All these are leading to rapid decline in momala variety. Moreover, no detailed scientific evaluation of the nutritional aspects of this variety has been undertaken so far. Therefore, immediate attention and measures are needed to document, evaluate, popularize and preserve this local variety. This research is aimed at filling this information gap, with the objectives of (i) exploring and documenting the traditional knowledge of local farmers in cultural agro-management of maize or corn, (ii) describing the traditional utilization of momala, and (iii) investigating the nutritional composition of momala.

\section{MATERIALS AND METHODS}

\section{Research sites}

This study was conducted from March to December 2018 in two villages of Gorontalo Province, Indonesia, namely Biluhu Barat Village (Bonebolango District) and Wumialo Village (Gorontalo City) (Figure 1).

A combination of qualitative and quantitative research methods was employed. It relied on observations and indepth interviews with the participants to collect qualitative ethnobotanical information pertaining to traditional agricultural management and utilization of maize variety (Montagne 1997).

This study used method was qualitative which is based on the ethnoecological biological approach (Martin 1995) Alburquerque et al. 2014) The field data to collect with techniques observation, participant observation, and interview. The observation was undertaken in the field, particular observation of the ecological condition of maize gardens, maize crops, and activities of farmers in managing of maize crop and processing of maize productions. The observation participation was carried out by involving researchers in various activities of farmers in managing the maize farming, including planting and harvesting of maize in the gardens, and processing of maize production in the farmers' houses. While the interview was applied with a deep interview or semi-structured-interview with local experts or competent informants which are purposively selected by the snowball technique (ef. Martin 1995).

The quantitative method was applied to analyze and evaluate the nutritional value of the momala maize. The proximate composition analysis focused on examining the composition of ash, protein, fat, and carbohydrate, while the mineral analysis examined the composition of Magnesium (Mg), zinc ( $\mathrm{Zn})$, phosphate $(\mathrm{P})$, calcium $(\mathrm{Ca})$, potassium $(\mathrm{K})$, copper $(\mathrm{Cu})$ and manganese $(\mathrm{Mn})$. Proximate analysis was conducted in the laboratory of the Faculty of Veterinary Medicine, Universitas Airlangga, Surabaya, Indonesia using analysis method from National Standardization Agency of Indonesia (SNI) (SNI 01-28911992) and Association of Official Analytical Chemists (AOAC 2001). Analysis of mineral composition was conducted in the Center for Health Laboratory, Universitas Airlangga, Surabaya, Indonesia using AAS method (Atomic Absorbent Spectrophotometry) (Murningsih et al. 2018).

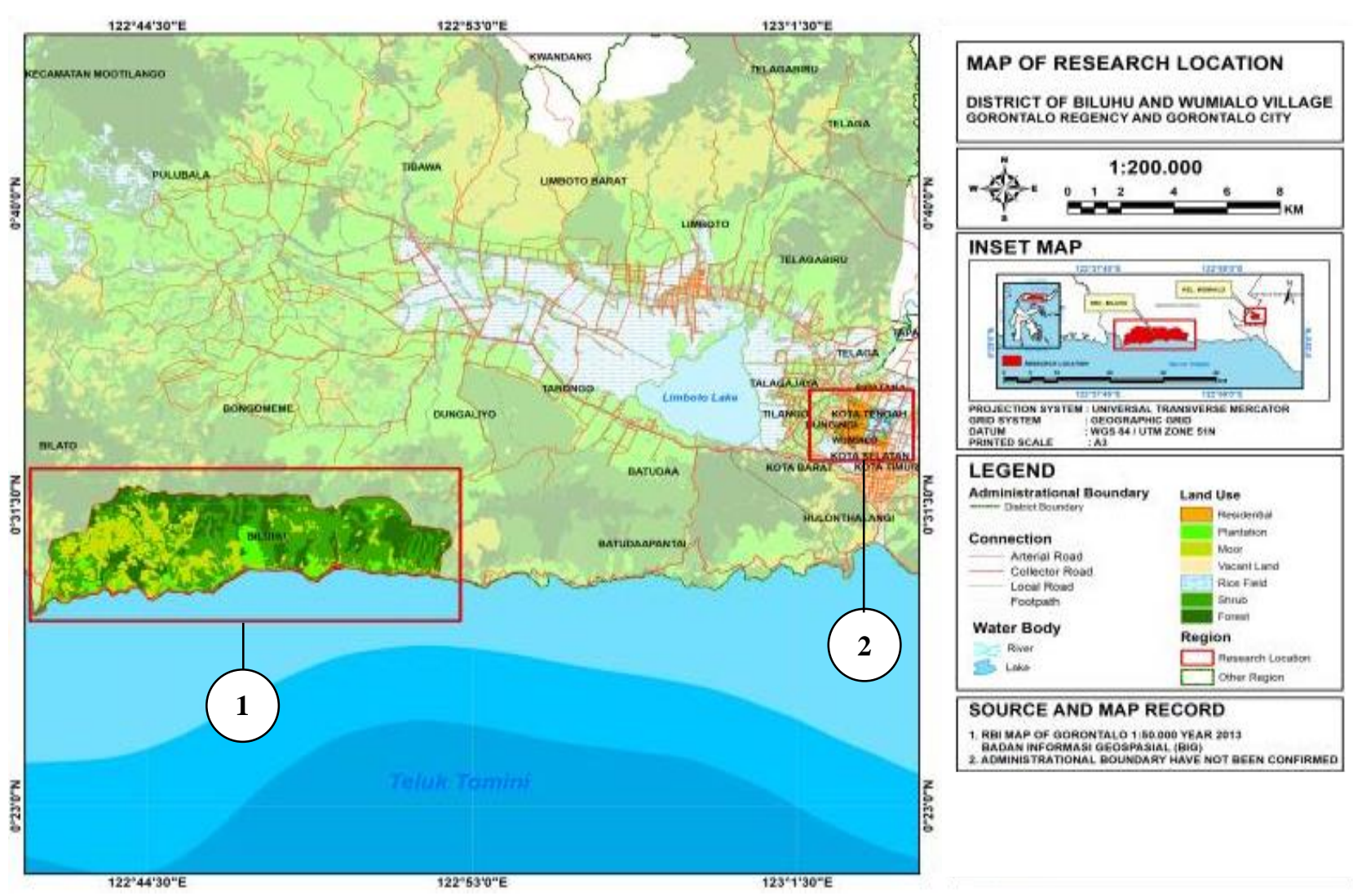

Figure 1. Research sites in Biluhu Barat Village, Bonebolango District (1), and Wumialo Village, Gorontalo City (2), Gorontalo Province, Indonesia 


\section{Analysis of ash content (SNI 01-2891-1992)}

As many as two to three grams of the sample was inserted into an evaporating dish, the sample in the dish was charred on top of a Bunsen burner. The sample was further charred again in an electric arc furnace with a maximum temperature of $550{ }^{\circ} \mathrm{C}$ until the charring process was completed (the door of the furnace is usually left open a bit for allowing the oxygen flow into the furnace). Following this process, the sample was allowed to cool down in a desiccator. The sample was also weighed until its weight remained constant.

$$
\text { Ash content }=\underline{\mathrm{W}_{1}} \underline{-\mathrm{W}_{2}} \underline{\mathrm{W}} \underline{\mathrm{x}} 100 \%
$$

W : weight before charring process $(\mathrm{g})$

$\mathrm{W}_{1}$ : weight of the sample + dish after the charring process $(\mathrm{g})$

$\mathrm{W}_{2}$ : weight of the empty dish (g)

\section{Crude protein analysis (AOAC 2001)}

As many as $0.1 \mathrm{~g}$ of the sample was mixed with $1 \mathrm{~g}$ of catalyst (made by mixing $1 \mathrm{~g}$ of copper sulfate $\mathrm{CuSO}_{4}$ and $1.2 \mathrm{~g}$ of $\mathrm{NaSO}_{4}$ or sodium sulfate) and $2.5 \mathrm{~mL}$ of concentrated sulfuric acid $\left(\mathrm{H}_{2} \mathrm{SO}_{4}\right)$. This mixture was heated in a Kjeldahl Flask until its color turned vivid. The mixture was then cooled and diluted until $100 \mathrm{~mL}$. $5 \mathrm{~mL}$ of the sample was inserted into a distillation apparatus, the distillation process was stopped once the distillate volume becomes twice the original volume (the volume before the distillation process). The distillate was further titrated with $0.02 \mathrm{~N}$ sodium hydroxide $\mathrm{NaOH}$, two drops of red methylate and blue methylate (Mengsel) was also added. The same treatment can also be applied to blank solution.

Protein $=\underline{m L \text { titration (blank solution }- \text { titration) } \times \text { N 14.007 } \times 6.25} \times 100 \%$ Weight of the sample (g) $\times 1000$

\section{Analysis of crude fat content (SNI 01-2891-1992)}

One to two grams of sample was inserted into a paper tube, the bottom side of the paper was covered with cotton. The sample was dried in an oven with a temperature not exceeding $80^{\circ}$ for approximately an hour. Further, the sample was inserted into a soxhlet apparatus that had been connected to a boiling flask containing dried boiling stone of known weight. The process was followed by the extraction using hexane or other fat solvents for about six hours. The hexane was filtered, and the fat extract was dried in an oven at the temperature of $105{ }^{\circ} \mathrm{C}$. Afterward, the sample was cooled down and weighed. The drying was replicated until the sample's weight remained constant.

$$
\begin{aligned}
& \% \text { fat }=\frac{\mathrm{W}-\mathrm{W}_{1}}{\mathrm{~W}_{2}} \times 100 \% \\
& \mathrm{~W} \quad \text { : weight of sample }(\mathrm{g}) \\
& \mathrm{W}_{1} \quad \text { : weight of flask before extraction }(\mathrm{g}) \\
& \mathrm{W}_{2} \quad \text { : weight of flask after extraction }
\end{aligned}
$$

\section{Analysis of carbohydrate content (SNI 01-2891-1992)}

As many as five grams of sample was inserted to a 500 mL Erlenmeyer flask. Further $200 \mathrm{~mL}$ of $3 \%$ hydrochloric acid or $\mathrm{HCl}$ was added; the mixture was heated for three hours using a Liebig condenser. The mixture was cooled down and neutralized using sodium hydroxide $30 \% \mathrm{NaOH}$ (using litmus or phenolphthalein). $3 \% \mathrm{CH}_{3} \mathrm{COOH}$ (acetic acid) was added to the mixture, so that the solution becomes a bit acidic. The mixture was moved to a $500 \mathrm{~mL}$ of volumetric flask until it reached the marked line, and was filtered. $10 \mathrm{~mL}$ of filter was added into a $500 \mathrm{~mL}$ Erlenmeyer flask. Following this step was adding $25 \mathrm{~mL}$ of luff solution (using a pipette), boiling stones, and $15 \mathrm{~mL}$ of distilled water. All of the mixtures were heated at a constant temperature. The solution brought to its boiling temperature in three minutes (using a timer). The boiling process continued until 10 minutes right after the mixture reached its boiling temperature and cooled down in a tub of ice immediately. Once the mixture was cooled, $15 \mathrm{~mL}$ of $20 \%$ potassium iodide and $25 \mathrm{~mL}$ of $25 \%$ sulfuric acid was poured slowly. The mixture was titrated using $0.1 \mathrm{~N}$ thio (using the $0.5 \%$ of starch solution), and then proceed with the blank solution.

$$
\text { Glucose content }=\underline{\mathrm{W}}_{1} \frac{\mathrm{x \textrm {fp } \times 1 0 0 \%}}{\mathrm{W}}
$$

Level of carbohydrate: $0.90 \times$ level of glucose

$\mathrm{W}_{1}$ : weight of sample $(\mathrm{g})$

$\mathrm{W}_{2}$ : content of glucose for every $\mathrm{mL}$ of thio used from the list

fp : dilution factor

\section{Data analysis}

The collected data was analyzed by crosschecking, summarizing, synthesizing, and built up a narrative with descriptive analysis and evaluative (Newing et al. 2011)

\section{RESULTS AND DISCUSSION}

\section{Traditional agro-management of maize}

Agricultural land for maize planting in Biluhu Village is $180 \mathrm{Ha}$. The total maize yield is 846 tons, and its productivity is around 2.6 tons/Ha. The agricultural land of the village is dominated by hills. Maize farmers in the village grow maize in area having 25 to $40 \%$ slope (BPS 2016). The agricultural areas in Wumialo Village are mostly flatlands, and the percentage of the area used for growing maize is only $0.54 \%$ (BPS 2018).

The farmer community in Biluhu Village implements the principle of huyula (a term derived from Gorontalo language) in managing the agricultural area. In this practice, each farmer takes turn in organizing the agricultural activities, which range from land clearing, planting, weeding, harvesting, and removing corn kernels. The maize farmers in Wumialo Village, in contrast, apply different concepts in their agricultural activities; they apply mainly the daily wage system. 
Maize filled with mature kernels on all sides of the cob or ear is the preference of farmers for preparing corn seeds for planting. The husks of the corn are put together and tied on a bamboo. The bamboo is then put on a fireplace (which is called dodika in Gorontalo language); the fuel used is mostly firewoods or coconut shells. This process is to ensure that the prepared kernels are free from pests.

Momala, the local maize variety, is recognized for its long size and unique clumping characteristic. Each maize plant may contain two to five cobs or ears. The plant height is $146.47 \mathrm{~cm}$ on average; the average cob height is 73.88 $\mathrm{cm}$, with the average stem perimeter of $8.46 \mathrm{~cm}$. In one plant, the number of the leaves is 12 on average, where the average leaves strand is $86.59 \mathrm{~cm}$; the average leaves midrib is $16.25 \mathrm{~cm}$ with an average width of $8.71 \mathrm{~cm}$. The leaves are a bit curving with pointed tips. Besides, the average axilla corner is 39.950 ; the grain is $5.86 \%$, and the husk is $83.76 \%$. Average cob length is $12.58 \mathrm{~cm}$; average cob diameter is $3.34 \mathrm{~cm}$; average cob weight with its husk is $88.58 \mathrm{~g}$, average cob weight without husk measures at $60.74 \mathrm{~g}$, average kernel number per line is 20 , and weight of 1000 grains measures at $272 \mathrm{~g}$ (Suleman et al. 2019).

The farmers plant two kernels per planting pot; this is to ensure at least one germinates. Male and female farmers have their roles distributed while planting the corn. Men generally prepare the land and planting plots while the women plant the kernels. In growing local maize, farmers are not accustomed to irrigation or fertilization. They harvest the maize for specific purposes. For example, the farmers harvest the crop in 45 to 60 days after planting, if their preference is baby corn. Stover that is still fresh is used for feeding cows. The farmers let the corn to dry and harvest it after 90 to 100 days of planting, if they need old corn. The stem and leaves are cut and left to rot. During the new planting season, farmers grow the maize manually using traditional methods or relying on animals, such as cows, to plow the land (this process is referred to as pajeko in Gorontalo language).

The maize farmers to start planting corn usually pay attention to the right planting time, according to the instructions of the Elders who know the astronomy system. Astrologers (Panggoba, in Gorontalo language) with their local experience and knowledge can determine the right time to start an activity, including the time to plant a cultivation crop. Such an agricultural practice shares some similarities with the system of dryland farming of Baduy community. Local knowledge of the Baduy forest community is adaptive to their environment. They rely on environmental indicators, such as the position of constellations, flowering period, and traditional, custombased agricultural calendar system (Iskandar 2015).

\section{Utilization of momala}

Details regarding the utilization of momala in preparation of various food items are provided in Table 1. According to the interview data as shown in Table 1, the kernels of momala (both young and old kernels) are used as the ingredient of some traditional foods. The kernels are processed to corn starch to be used as the ingredient of some traditional cakes. The byproduct of the plant, consisting of stalk and leaf of the plant, are also processed into straw for animal feeds. The utilization of momala is similar to the use of Manado Kuning variety which has been reported to be utilized for purposes, including as ingredient of food (processed into starch), and as animal feed. In Tompaso, Manado Kuning variety is used as animal feed since the area has a lot of racehorses (Runtunuwu et al. 2014). The use of coconut in some maize or corn dishes is similar to Kukuruwu, a traditional food of Baduy tribe (Iskandar 2015). Information about the utilization of maize or corn as the ingredient of many high nutrient foods has been integrated into learning activities at schools. This has been stipulated in the Regulation of Regional Government of the Province of Gorontalo No. 3 of 2015 considering the Gorontalo Traditional CuisineBased Nutrition Studies. Maize is among the main ingredients of traditional food of Gorontalo (Peraturan Daerah Provinsi Gorontalo 2015).

\section{Nutritional value of momala maize}

The results of analysis of proximate composition of momala maize found in Biluhu and Wumialo Villages are summarized in Table 2. This table indicates a difference in the composition of protein and basal energy without nitrogen, between the samples of Biluhu and Wumialo villages. The difference is thought to be influenced by soil fertility. Especially when planting maize without fertilization The distribution of carbohydrates and nutrients varies significantly among the corns' stover fraction and research sites (Mourtzinis et al. 2016). The protein content of momala is different from that of Pena Tunu 'Ana', the local variety of Nusa Tenggara Timur, which has protein content of $11.78 \pm 0.05 \%$. However, the protein content of momala is higher than other local varieties, such as Piet Kuning, Gumarang and Lamuru (Murningsih et al. 2018). The protein content of momala is also greater than Manado Kuning variety, having $7.71 \%$ of protein (Landeng et al. 2017). When compared with hybrid corn, the protein content of momala corn is higher than Bisi 2, while the carbohydrate content in Bisi 2 is higher than momala. Bisi 2 has a protein content of $8.40 \%$, carbohydrates $75.10 \%$ (Suarni 2017). Maize or corn with the protein content above $9 \%$ meets the SNI standard (1998) of a minimum percentage of $7.5 \%$; the maize is also considered highprotein corn, and such corn can be used as the ingredient of foods, e.g., bread, biscuits, cakes, and other high-protein foods. The proximate composition of momala is also higher than other maize varieties of Kaduna, Nigeria, in which the carbohydrate percentage range was $44.8-69.6 \%$, protein content $4.5-9.87 \%$, moisture content $11.6-20 \%$, fiber content $2.10-26.77 \%$, fat content $2.17-4.43 \%$, and the ash content was 1.10-2.95\% (Enyisi et al. 2014). All genotypes of maize have substantial differences in terms of their chemical and mineral composition (Kabir et al. 2019). On the other hand, the lowest amount of carbohydrate and protein was found in BHM-15 (77.67\%) and BHM-8 $(10.96 \%)$. BHM-13 contains the lowest amount of fiber (1.24\%) and fat (4.27\%) (Kabir et al. 2019). 
Table 1. The utilization of momala maize of Gorontalo Province, Indonesia

\begin{tabular}{|c|c|c|c|}
\hline Name of food product & $\begin{array}{c}\text { Utilized } \\
\text { maize part }\end{array}$ & Other ingredients & Method of preparation \\
\hline $\begin{array}{l}\text { Balobinthe (rice mixed } \\
\text { with corn) }\end{array}$ & Old corn & Rice & $\begin{array}{l}\text { - Add finely crushed old corn kernel to rice, in the ratio } \\
\text { of } 1: 3 \text {. Rinse the mixture of corn and rice. Pour the } \\
\text { mixture into a pan, add water to the pan and start } \\
\text { cooking the rice in a rice cooker. }\end{array}$ \\
\hline
\end{tabular}

Binthe biluti (pan-toasted corn kernels served with Ebi shrimp and shredded coconut)

\section{Binthe biluhuta (clear corn soup)}

Baby corn

Shredded semi-ripe coconut, fish or ebi shrimp, basil, chili/pepper, chives, onion, calamansi lemon (Citrus microcarpa), coconut oil, salt.

Baby corn

Cakalang fufu (smoked skipjack tuna), ebi shrimp, shredded semi-ripe coconut, rawit (bird's eye chili), shallots, basil, lemongrass, chives, calamasi lemon, salt, soy sauce.

Baby corn Coconut milk, hunkwe (mung bean) flour, sugar, pandan leaves corn and rice flour cake with sliced banana filling)

Gamie (traditional maize dish of Gorontalo)

Kokole (pudding-like corn cake)
Baby corn

Papaya leaf, banana blossom (putungo), shallot, chili, salt, shredded coconut.

Baby corn Coconut milk, brown sugar
- Boil corn and shrimp for 20 minutes. Lift the boiled corn and drain. Pan sear the corn.

- In a bowl, stir shredded coconut, shrimp or fish, basil, sliced green onion, and salt. Add calamasi lemon juice to the bowl.

- Add the corn to the bowl, stir it and add fried onions for the topping.

- Boil corn and 1 stalk of lemon grass for 20 minutes until done.

- Sauce: Grind together 15 bird's eye chili and 2 cloves of shallots, add salt.

- Remove bones from the smoked fish, shred the fish.

- Add slices of green onion, shredded fish, basils, salt, and lemon juice to the boiled corn.

- Stir it well. Binthe biluhuta can be served with chili paste and soy sauce.

- Shred or mash corn until smooth.

- In a bowl, pour some water, sugar, and pandan leaves; boil until cooked. Add the mashed corn to the bowl.

- Pour hunkwe powder, set the stove to medium heat. Add the corn batter to the hunkwe batter. Stir the mixture until thickened. Chill the batter.

- Scoop the mixture onto the center of the banana leaf. Fold into a nice packet. Place the wrapped cake into a steamer. Steam it for 20 minutes until done. Takes the cake out from the steamer and serve at room temperature.

- Boil baby corn. Shred semi-ripe coconut.

- Slice papaya leaf and banana blossom, pour these into mashed shallot and chili.

- Add shredded coconut to the mixture. Stir it well. The mixture is served with boiled corn.

- Blend kernels of the corn until smooth. The blended corn is then filtered, so that corn extract is obtained.

- Melt brown sugar until it melts.

- In a bowl pour the corn extract, shredded coconut, and melted brown sugar; stir it well. Cook the mixture until boiling and thickened. Pour the mixture into a pan that has been greased with coconut oil to keep the batter from sticking. Chill the dough or batter. Kokole is better served cold.
The mineral composition of momala corn is shown in Table 3. The mineral content of momala is lower than Tunu 'Ana', the local maize variety of East Nusa Tenggara, Indonesia. Tunu 'Ana' contains $127.50 \pm 0.00 \mathrm{mg} / 100 \mathrm{~g}$ of magnesium, $310.00 \pm 0.01 \mathrm{mg} / 100 \mathrm{~g}$ of Potassium, 450.00 $\pm 0.00 \mathrm{mg} / 100 \mathrm{~g}$ of phosphor, which is greater than three varieties of maize, such as Gumarang), Lamuru and Piet Kuning (Murningsih et al. 2018). In comparison with these maize varieties, the content of magnesium in momala is only $0.122 \mathrm{mg} / \mathrm{kg}$, contains $0.316 \mathrm{mg} / \mathrm{kg}$ of phosphate and contains $0.413 \mathrm{mg} / \mathrm{kg}$ potassium. 
Table 2. Proximate composition of momala variety of corn

\begin{tabular}{lcc}
\hline $\begin{array}{l}\text { Proximate } \\
\text { composition }\end{array}$ & $\begin{array}{c}\text { Momala of Biluhu } \\
\text { Village (Bonebolango } \\
\text { District) }\end{array}$ & $\begin{array}{c}\text { Momala of Wumialo } \\
\text { Village } \\
\text { (Gorontalo City) }\end{array}$ \\
\hline Dried material (\%) & $90.37 \pm 3.58$ & $87.83 \pm 2.67$ \\
Ash (\%) & $2.39 \pm 0.66$ & $1.35 \pm 0.01$ \\
Protein (\%) & $9.56 \pm 0.66$ & $11.51 \pm 0.24$ \\
Crude fat (\%) & $4.64 \pm 0.11$ & $4.62 \pm 0.48$ \\
Carbohydrate (\%) & $68.16 \pm 0.43$ & $67.68 \pm 0.67$ \\
Basal energy without & $71.09 \pm 2.64$ & $58.36 \pm 0.93$
\end{tabular}

nitrogen

Energy kcal/100 g $\quad 3274.42 \pm 110.81 \quad 2886.25 \pm 14.68$

Note: Data is the average \pm standard deviation of 2 replications

Table 3. Mineral composition of momala variety of corn

\begin{tabular}{lc}
\hline \multicolumn{1}{c}{ Parameter } & Result $(\mathbf{m g} / \mathbf{k g})$ \\
\hline Magnesium $(\mathrm{Mg})$ & $0.122 \pm 0.0028$ \\
Zinc $(\mathrm{Zn})$ & $0.005 \pm 0.0021$ \\
Phosphate $(\mathrm{P})$ & $0.316 \pm 0.0057$ \\
Calcium $(\mathrm{Ca})$ & $0.046 \pm 0.0071$ \\
Potassium $(\mathrm{K})$ & $0.413 \pm 0.0071$ \\
Copper $(\mathrm{Cu})$ & $0.001 \pm 0.0001$ \\
Manganese $(\mathrm{Mn})$ & $0.003 \pm 0.0007$ \\
\hline
\end{tabular}

Momala is also recognized with its distinctive purple kernels and female flowers ( PVP 2018); Suleman et al. 2019). These diverse morphological characters could possibly be influenced by many factors, such as genetic factors and environmental factors. That variations in the phenotypic appearance of plants can be caused by differences in plant characters (genetic), differences in environmental conditions, or interactions of the two factors (Sinay and Karuwal 2018). In addition to this, the presence of purple color in the momala corn plant is suspected that the momala corn has a high anthocyanin content. The presence of anthocyanin acts as an antioxidant to prevent atherosclerosis, a blood vessel obstruction High anthocyanin content is assumed to be the cause of such uniqueness of momala. Anthocyanin, as an antioxidant, can prevent atherosclerosis, a disease obstructing blood flow (Balitsereal 2019).

Momala plays a major role in the food security of local people. In spite of that, this local variable is not preferred by most farmers, as it is difficult for them to get the seeds of this maize. This issue demands solutions, such as conserving and developing momala maize. One of the efforts is to improve the national maize productivity by setting time for cultivation and determining the spaces between the plants during the planting of hybrid and local maize (this is to prevent natural hybridization between these maize varieties). In addition, momala corn should be properly fertilized to improve its proximate composition and mineral content which can make it nutritionally rich.

\section{ACKNOWLEDGEMENTS}

We extend our gratitude to all the local farmers for their willingness to participate in the interview process and share their knowledge.

\section{REFERENCES}

Albuquerque UP, Cruz da Cunha LVF, Lucena RFP, Alves RRN (eds.). (2014. Methods and Techniques in Ethnobiology and Ethnoecology. Springer, New York.

AOAC. 2001. AOAC Guidelines for Single Laboratory. AOAC International, Rockville, MD.

BPS [Badan Pusat Statistik]. 2016. Kabupaten Boalemo dalam Angka 2016. BPS Kabupaten Boalemo. BPS, Boalemo. [Indonesian]

BPS [Badan Pusat Statistik]. 2018. Kota Gorontalo dalam angka. BPS, Kota Gorontalo. [Indonesian]

Balitsereal. 2019. Jagung Ungu. Balai Penelitian Serealia, Maros. [Indonesian]

Enyisi SI, Umoh V, Whong C, Abdullahi I, Alabi O. 2014. Chemical and nutritional value of maize and maize products obtained from selected markets in Kaduna State, Nigeria. African J Food Sci Tech 5 (4): 2141-5455. DOI: 10.14303/ajfst.2014.029

Hwang T, Ndolo VU, Katundu M, Nyirenda B, Bezner-Kerr R, Arntfield S, Beta T. 2016. Provitamin A potential of landrace orange maize variety (Zea mays L.) grown in different geographical locations of central Malawi. Food Chem 196: 1315-1324. DOI: 10.1016/j.foodchem.2015.10.067

Iskandar J. 2015. Studi etnobotani keanekaragaman tanaman pangan pada "Sistem Huma" dalam menunjang keamanan pangan Orang Baduy. In Pros Sem Nas Masy Biodiv Indon 1265-1272. DOI: 10.13057/psnmbi/m010601. [Indonesian]

Kabir SH, Das AK, Rahman MS, Singh MS, Morshed M, Marma ASH. 2019. Effect of genotype on proximate composition and biological yield of maize (Zea mays L.). Archive Agri Envir Sci 4 (2): 185-189. DOI: $10.26832 / 24566632.2019 .040209$

Karigidi KO, Olaiya CO. 2019. Antidiabetic activity of corn steep liquor extract of Curculigo pilosa and its solvent fractions in streptozotocininduced diabetic rats. $\mathrm{J}$ Trad Comp Med. DOI: 10.1016/J.JTCME.2019.06.005

Landeng PJ, Suryanto E, Momuat LI. 2017. Komposisi proksimat dan potensi antioksidan dari biji jagung manado kuning (Zea mays L.). 10 (1): 36-44. R

Martin GJ. 1995. Ethnobotany: a Methods Manual. Chapman and Hall, London.

Montagne M. 1997. Ethnobotany: Principles and Applications By Cotton CM. John Wiley and Sons Ltd, Baffins Lane, Chichester, West Sussex, England. J Med Chemis 40 (13): 2108-2108. DOI: 10.1021/jm9701841

Mourtzinis S, Cantrell KB, Arriaga FJ, Balkcom KS, Novak JM, Frederick JR, Karlen DL. 2016. Carbohydrate and nutrient composition of corn stover from three southeastern USA locations. Biomass Bioener 85: 153-158. DOI: 10.1016/j.biombioe.2015.11.031

Murningsih T, Yulita KS, Bora CY, Arsa IGB. 2019. Proximate and mineral content of maize landrace (tunu'ana') from East Nusa Tenggara. Pros Sem Nas Masy Biodiv Indon 5: 107-111. DOI: 10.13057/psnmbi/m050120

Newing H, Eagle CM, Puri WC. 2011. Conducting Research in Conservation: A Social Science Perspective/Social Science Methods and Practice. Routledge, London.

Peraturan Daerah Provinsi Gorontalo. 2015. Perda Provinsi Gorontalo Nomor 3 Tahun 2015 tentang Pembelajaran Ilmu Gizi berbasis Makanan Volume 151. Gorontalo. [Indonesian]

PVT [Pusat Perlindungan Varietas]. 2018. Berita Resmi PVT Pendaftaran Varietas Lokal. $\quad$ Retrieved from http://pvtpp.setjen.pertanian.go.id/berita-resmi/pendaftaran-varietaslokal/. [Indonesian]

Runtunuwu SD, Pamandungan Y, Mamarimbing RM. 2014a. The exploration of manadonese yellow maize germplasm in North Sulawesi. Jurnal Bios Logos 2 (1): 56-64. DOI: 10.35799/jbl.4.2.2014.6353. [Indonesian] 
Sinay H, Karuwal RL. 2018. Short communication: Genetic variability of local corn cultivars from Kisar island, Maluku, Indonesia based on morphological characters. Biodiversitas 19 (6): 2302-2307. DOI: 10.13057/biodiv/d190638

Suarni SW. 2017. Struktur, Komposisi dan Nutrisi Jagung. In Jagung: Teknologi dan Pengembangan Jagung. Balai Penelitian Tanaman Serealia, Maros. [Indonesian]

Suleman R, Kandowangko NY, Abdul A. 2019. Karakterisasi morfologi dan analisis proksimat jagung (Zea mays L.) varietas momala gorontalo. Jambura Edu Biosfer Journal 1 (2): 72-81. DOI: 10.34312/jebj.v1i2.2432.

Subekti N, Syafruddin R, Sunarti S. 2007. Morfologi tanaman dan fase pertumbuhan jagung. Balai Penelitian Tanaman Serealia, Maros. [Indonesian]

SNI. 1992. SNI 01-2891-1992 Cara Uji Makanan dan Minuman. [Indonesian] 